Reprinted from the "Proceedings of the Indian Academy of Sciences," Vol. LII, 1960

\title{
A NEW GENUS OF THE LOPHOTHALIEA FROM INDIA
}

BY

R. Prasanna Varma 
Eeprinted from "The Proceedings of the Indian Acdiemy of Sciences", Vol. LII, No.2, Sec. B, 1960

\title{
A NEW GENUS OF THE LOPHOTHALIEA FROM INDIA*
}

\author{
By R. Prasanna Varma \\ (Central Marine Fisheries Research Station) \\ Received May 5, 1960 \\ (Communicated by Dr. S. Jones, F.A.sc.)
}

THE alga which is described here was collected from the Pearl oyster beds off Tuticorin during January and March 1959. This alga was common on the shells of pearl oysters collected from the Karuval Paars (both Karai and Velangu Karuvals), 14-18 metres deep.

The plants, purple brown in colour, were growing on the shells of pearl oysters and attached by means of unbranched rhizoids, which were anchored to sand particles on the shells by disc-like tips. These rhizoids are formed exogenously by the pericentral cells of the older regions of the prostrate fortions of the plants. They are often three-celled (Plate II, Fig. 7), rarely twoto five-celled. The erect portion arising from the prostrate portions attains a height of 4-7 cm. Superficially they resemble a Polysiphonia except for a dense clothing of persistent, coloured, lateral trichoblasts (Platé I, Fig. 1 and Plate II, Fig: 4).

The alga grows by an apical cell, $13-15 \mu$ long and 8-10 $\mu$ broad (Plate I, Fig. 3). This apical cell cuts off the trichoblast initial and four pericentral cells. The order of formation of the pericentral cells is indicated in TextFigs. 1-6. The fully developed axis consists of a central cell $22-25 \mu$ diameter and surrounded by four pericentral cells. The diameter of the older region is $180-210 \mu$ and the length of a segment is $113-145 \mu$. Cortex is absent.

The lateral branches are persistent and monosiphonous. They arise from near the top of the central cells (Plate II, Fig. 6 and Text-Figs. 7 and 8). These lateral branches are arranged spirally on the axis, anticlockwise, every fifth lateral branch coming in a line on the same side as the first, i.e., $\frac{1}{4}$ spiral. Their formation in relation to the axis is indicated in Text-Figs. 7-14. A well-developed lateral branch measures about 8-12 mm. and consists of two (rarely three) small quadratic or slightly cylindrical cells at the base, a

- Published with the permission of the Chief Research Officer, Central Marine Fisheries Reseatch Station. 
very large flabellate cell in the middle, a small cell above and terminated by two very small cells, the distal of which being mucronate. Sooner or later the small basal cells shrink to form a neck connecting the trichoblast with the main axis. Even from the very early stages the flabellate cell is easily distinguishable (Plate I, Fig. 3). At the broadest part, these trichoblasts are $97-105 \mu$ broad.

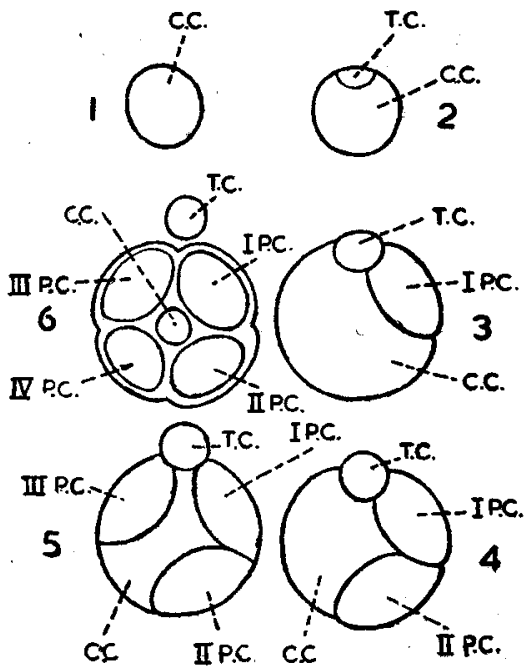

Texr-Figs. 1-6 (Diagrammatic): The order of formation of the pericentral cells and the position of the trichoblast cell in relation to the pericentrals.

C.C., central cell; T.C., Trichoblast initial; P.C., pericentral cell (I, II, III, IV representing the pericentral cells in the order of formation.

Most of the plants collected were without fruit bodies or had only tetrasporangia. The development of the tetrasporangia is similar to that described by Iyengar and Balakrishnan (1950) for Polysiphonia platycarpa Boergesen. Tetrasporangia are arranged spirally on the terminal regions of the branches and of the main axis (Plate I, Fig. 2). During their formation a basal sterile cell and two cover cells are differentiated.

Only one specimen with two cystocarps was found in the present set of collections (Plate II, Fig. 5). But unfortunately, the material got damaged while cutting sections and hence details of the cystocarp formation could not be followed. As this material is not available either as a herbarium specimen or as a permanent mount on slide, Plate II, Fig. 5 may be considered as a paratype. No antheridial plant was met with in the collections.

This alga belongs to the Rhodomelaceæ and comes under the sub-family Lophothaliea or the Lophothalia group of Kylin (1956). In the absence of 
specialized stichidial branches, in the presence of four pericentral cells, in the absence of cortication and in the formation of persistent coloured monosiphonous lateral branches, the present alga comes very close to Veleroa of Dawson (1944). The latter is monotypic and is based on $V$. subulata Dawson. Only tetrasporic plants were recorded by Dawson. It differs markedly in the characteristic flabellate shape of the unbranched laterals .(trichoblasts).

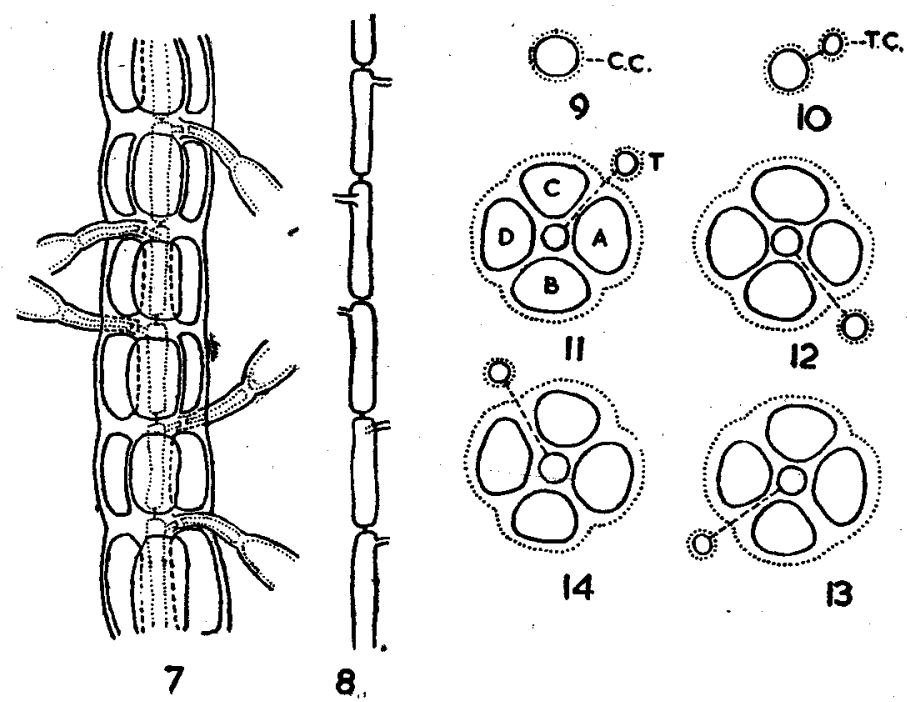

. Texr-Figs. 7-14 (Diagrammatic): Fig. 7. Schematic representation of the thallus showing the relative positions of the axial cells, pericentral cells and trichoblasts in a fully mature part. Fig. 8. The origin of the trichoblasts from about the top of the central cells. Figs. 9-14. Represent the spiral formation of the trichoblasts, $\&$ spiral arrangement; each figure representing a successive segment from top downward.

(C.C., central cell; T.C., trichoblast cell.

The lateral branches in Veleroa, as is understood on the basis of $V$. subulata, - are many-celled, narrow and gradually tapering, all the cells being of uniform size and shape except the apical cell which is conical. Such characteristic flabellate lateral branches, as observed in my material, are not known in any other genus. These lateral branches bear a distant resemblance to the figures of Gonatogenia subulata J. Ag., given in Kylin (1956, p. 513, Fig. $406 \mathrm{C}$ ), but the flabellate cells in Gonatogenia are spermatangial stichidia. Further, Gonatogenia has five pericentral cells in the polysiphonous regions and in many other respects also it differs from the present alga. The present alga is therefore considered as a new genus and is named Lynkiella, after Professor H. Kylin. The specific name Karuvalensis indicates the locality (Karuval paars) from where the alga was collected. 
Diagnosis.-In English: Lynkiella Varma gen. nov.

Thallus purple brown in colour, polysiphonous with a central axial cell and four pericentral cells, monopodial, attached to the substratum by means of 2-5 celled rhizoids produced exogenously from the older regions; bearing a dense clothing of persistent coloured 6-7 celled long determinate lateral branches (trichoblasts), -middle cells of lateral determinate branches very prominently enlarged, many times longer than broad, flabellate. Tetrasporangia formed spirally on the polysiphonous axis; one sporangium per segment, development of sporangia as in Polysiphonia. Cystocarpic plants known. Male plants not known.

Type: Lynkiella karuvalensis Varma sp. nov.

Lynkiella karuvalensis Varma sp. nov.

Plants $4-7 \mathrm{~cm}$. tall, attached to calcarious substrata and sand partícles by means of rhizoids. Main axis in fully developed regions is $180-210 \mu$ thick; the length of a segment being 113-145 $\mu$. Trichoblasts arranged spirally, anticlockwise, $\frac{1}{4}$ spiral, $97-105 \mu$ broad and $8-12 \mathrm{~mm}$. long.

Type specimen collected on the shells of pearl oysters at Karai Karuval Paars near Tuticorin on 21-1-1959 and deposited in the C.M.F.R.S. Herbarium, RPV. 1038; Paratype collected at Velangu Karuval Paars on 11-3-1959 and deposited in the C.M.F.R.S. Herbarium, RPV. 1038-1, RPV. 1038-2 and RPV. 1038-3.

Diagnosis.-In Latin: Lynkiella Varma sp. nov.

Thallus purpureo-brunneus, polysiphonus, ornatus una cellula centrali et axiali et quadruplici cellula pericentrali, monopodialis, substrato fixus per rhizoideas binas-quinasve exogene productas in partibus maturioribus; thallus dense vestitus ramulis perstantibus coloratis 6-7 cellulas longis, determinatis, lateralibus (trichoblastis); cellulæ mediæ ramulorum lateralium determinatorum eminentissime dilatatæ, multo longiores quam latæ, flabellatæ. Tetrasporangia spiraliter formata insidentia axi principali polysiphono, singula singulis segmentis insidentia, evoluta ut in Polysiphonia. Plantæ cystocarpicæ cognitæ; plantæ masculinæ ignotæ.

Typus: species sequens.

Lynkiella karuvalensis Varma sp. nov.

Plantæ 4-7 cm. altæ, fixæ substrato calcareo et particulis arenosis pèr rhizoideas. Axis principalis, cum plene evolutus, $180-210 \mu$ crassus; ; segmenta 113-145 $\mu$ longa; trichoblasta spiraliter dispodita contra horologíi manus moventia, $\frac{1}{4}$ spiralia, $97-105 \mu$ lata, $8-12 \mathrm{~mm}$. longa. 

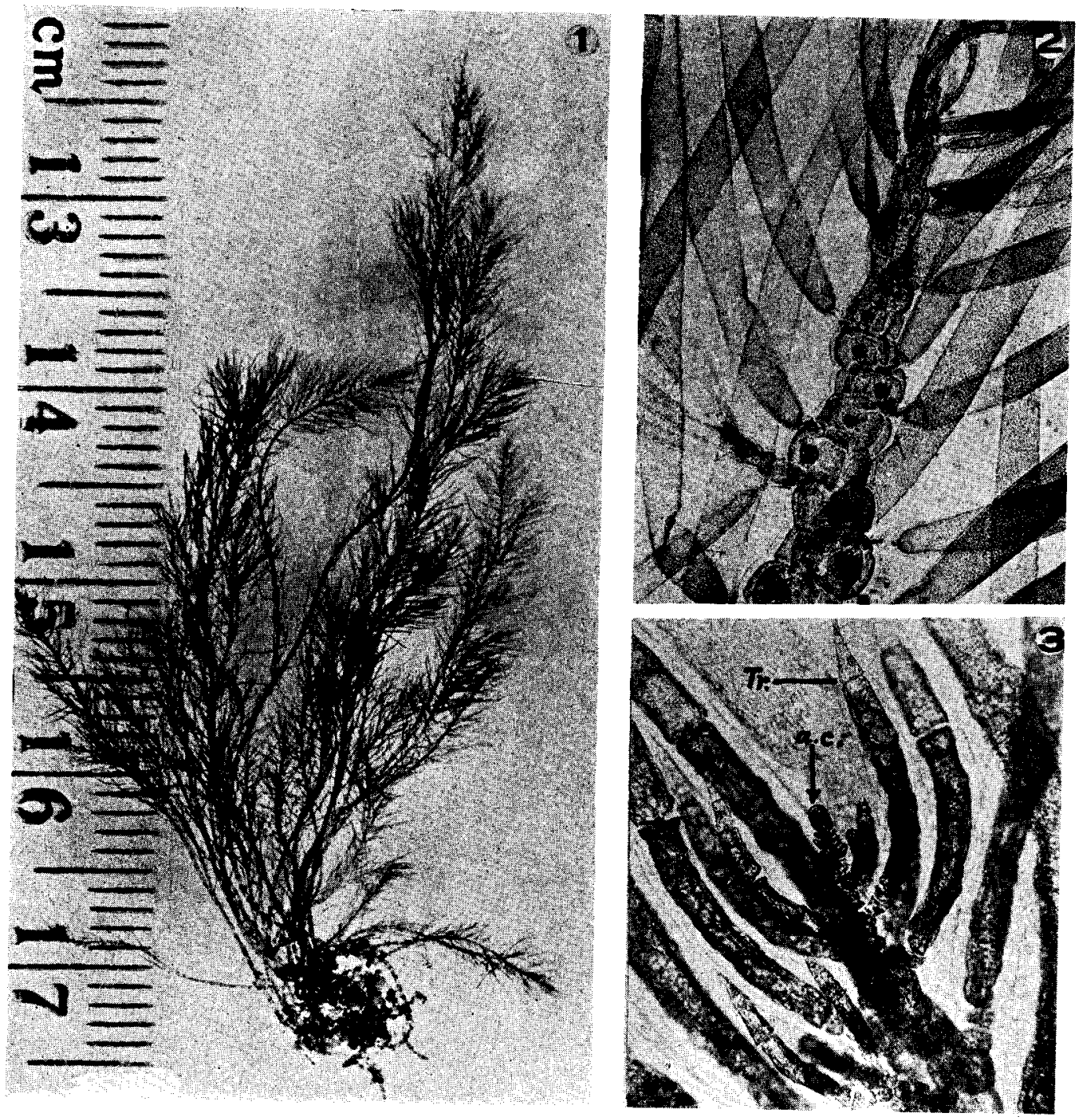

FIGS. 1-3 

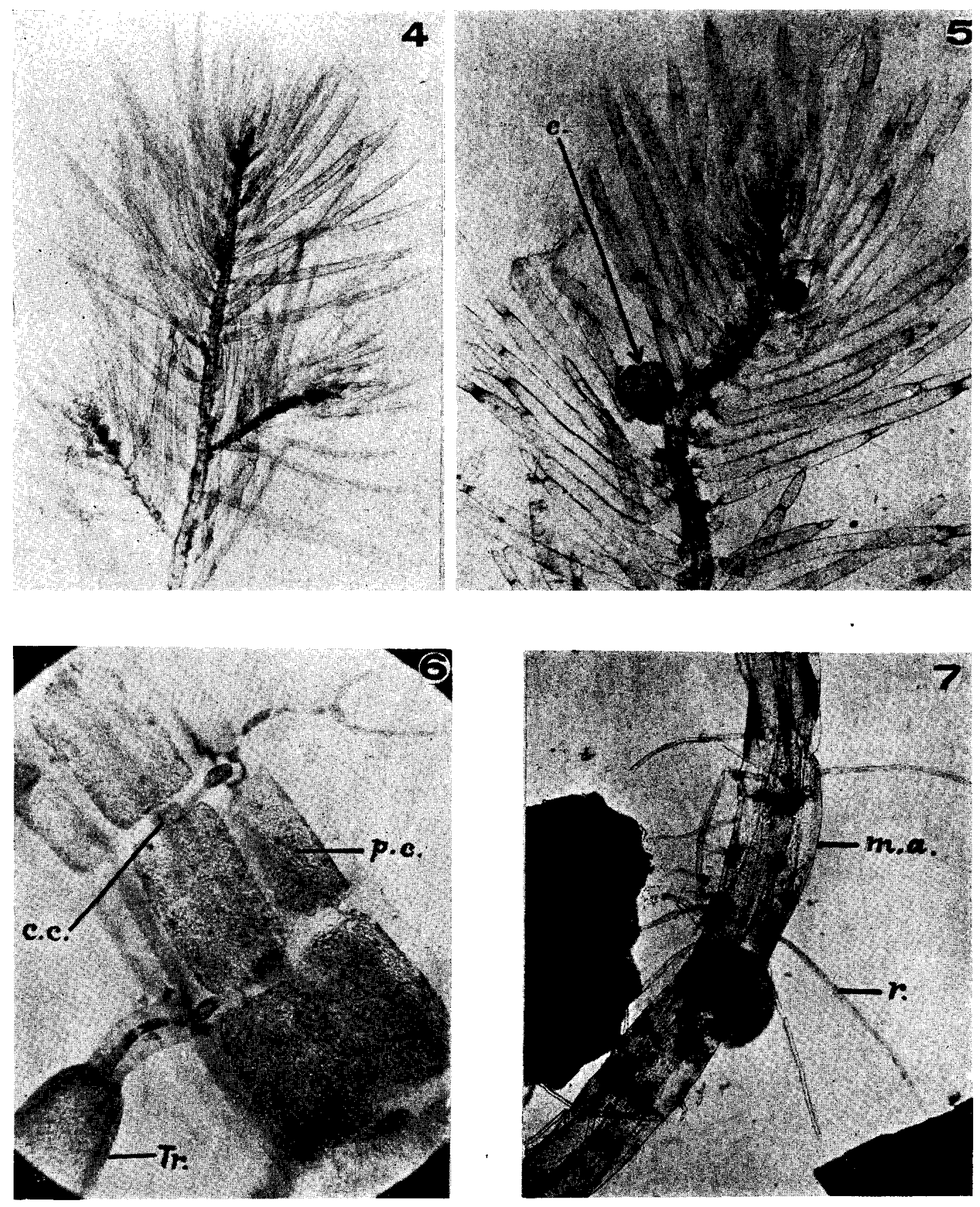
Typus lectus ostrearum conchis fixus ad Karai Karuval Paars prope Tuticorin die 21 januarii anni 1959 et positus in C.M.F.R.S. Herbario, sub numero RPV. 1038 ; paratypus lectus ad Velangu Karuval Paars die 11 mensis matii anni 1959 et positus in eodem herbario sub numeris RPV. 1038-1, RPV. 1038-2, RPV. 1038-3.

I am very grateful to Dr. S. Jones for the kind interest he has shown in this work. My thanks are also due to Dr. T. V. Desikachari for his very valuable criticisms and suggestions and to Rev. Father Dr. H. Santapau for kindly translating the diagnosis of the new genus and species into Latin.

\section{Dawson, E. Y. \\ Iyengar, M. O. P., and Balakrishnan, M. S. \\ Kylin, $\mathbf{H}$.}

\section{REFERENCES}

. "The marine algæ of the Gulf of California," Allan Hancock Pacific Exped., 1944, 3 (10), 189-454, 47 plates.

"Morphology and cytology of Polysiphonia platycarpa Boer. gesen," Proc. Ind. Acad. Sci., 1950, 31, 135-61.

. “Die Gattungen der Rhodophyceen," 1956, i-xv + 1-673, Glee-
$\quad$ rups, Lund.

\section{Explanation of Plates}

\section{Plate I}

Fro. 1. Entire plant, $\times 3 \cdot 4$.

FIG. 2. A tetrasporic branch showing the spiral formation of tetrasporangia, $\times 75$.

FiG. 3. Apex of the main axis showing the apical cell and a few trichoblasts, $\times 255$. (a.c., apical cell; Tr., Trichoblast).

\section{Plate II}

Fig. 4. A portion of the plant showing details of the axis and the persistent trichoblasts, $\times 13$.

Frg. 5. The cystocarpic branch with two cystocarps (Paratype), $\times 26$.

Frg. 6. Three segments of the axis showing the origin of the trichoblasts and their relation to the pericentral cells, $\times 193$.

FIG. 7. An older portion of the thallus showing the rhizoids arising from the pericentral cells, $\times 70$. (c., Cystocarp; c.c., Central cell; p.c., Pericentral cell; Tr., Trichoblast; m.a., main
axis of the prostrate system; r., Rhizoid). 